\title{
A Business Case Analysis Of The Snowboarding Industry
}

Kenneth A. Hunt Ph.D., Fort Lewis College, USA

Will Secor, USA

\begin{abstract}
This manuscript presents a business case analysis of the snowboarding industry. The demographic trends for both skiers and snowboarders are presented to illustrate the significant differences between the two. In addition, the historical growth of the industry is compared to that of the ski industry. Finally teaching notes offer suggestions as to how this case can be used in class to illustrate certain marketing and business principles.
\end{abstract}

Keywords: Business Case Study; Snowboarding Industry

\section{INTRODUCTION}

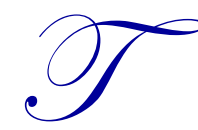

Day,")

he snowboarding industry can trace its roots back to 1929 when M. J. Burchett used wood and horse reins to make the first snow board like product. (Snowboarding2.com, 2006, par. 1). However, it is Sherman Poppen who is credited with creating the first real snowboard in 1965 . ("Back in the

Poppen credits his wife for coming up with the name of the new sled which the called "The Snurfer" which is "a contraction of snow and surf" (Flakezine, 1996, par. 6).

Two years prior to Sherman Poppen's breakthrough, a young boy named Tom Simms came up with a board for a class project which he called a 'Ski Board' (SBing2.com, 2006, par. 2) Regardless of who invented the first snowboard or when, the industry has grown into a multibillion dollar proposition. This case will investigate the snowboarding industry's history and its current state. In addition, the industry's demographics and marketing strategies will be presented.

\section{MARKETING THE SNURFER}

On Christmas day in 1965 Sherman Poppen made the first snurfer and within a year sold the idea to Brunswick (Flakezine, par. 12). Although the snurfer seemed like a modern snowboard it was sold in department stores as a children's toy ("Back in the day" 11).

"Between 1966 and 1977, Brunswick sold over half a million Snurfers through grocery stores and sporting goods shops all over the country" (Howe 6) "For the unbeatable price of $\$ 15$, one million snurfers were sold in the 10 years following, " ("Snowboarding History," par. 3).

\section{EVOLUTION OF THE SPORT}

In 1982 the first official competitions were held in Sioux City, Vermont ("Back in the day" 20). The very first Snow Snurfing Championships were organized by Paul Graves which gained recognition from Sports Illustrated, Good Morning America and the Today Show (thehistoryof.net, History of Snowboarding," par. 12). The contests participants competed in slalom and downhill events (methodmag.com, "History of Snowboarding," par. 19). This would mark the first time riders from around the world would be competing against each other in an official competition including, "rivals Tom Sims and Jake Burton Carpenter" (methodmag.com, "History of 
Snowboarding" par. 19). This event would influence the creation of Snowboarding organizations such as The International Snowboarding Federation (ISF) (Miller. "Snowboarding and the Rise to Olympic Competition," par. $3)$.

Also in 1982 Tom Simms heard a group of snowboarders in Lake Tahoe, California who, "rode a natural half-pipe of snow" (Howe 29). At that point in time a half-pipe was unimaginable for snowboarding and, "Usually made out of wood or concrete for skateboards" (Howe 29).

As time progressed, "more and more competitions were held and more and more snowboarders appeared on the slopes" (Miller. "Snowboarding and the Rise to Olympic Competition," par. 3). Eventually Jake Burton and Tom Simms held their own respective competitions and events in 1983 (Thehistoryof.net, "History of Snowboarding," par. 13).

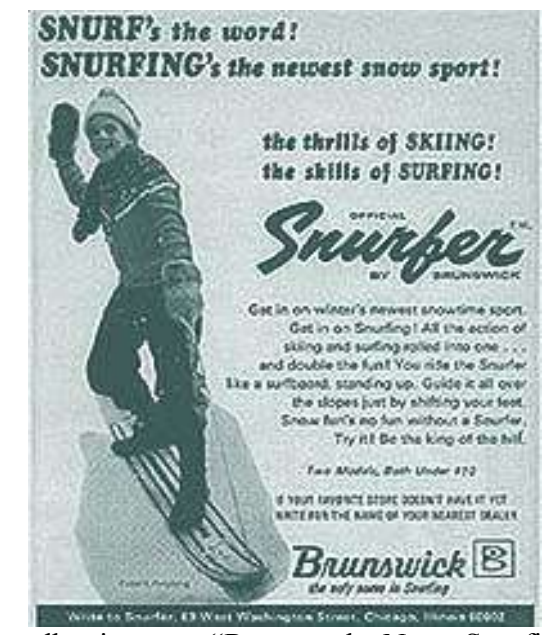

Source: Shreadbetties.com, "Rope on the Nose: Snurfing for Girls"

\section{THE CULTURAL SIDE OF SNOWBOARDING}

Although more and more snowboarders were starting to show up on the slopes, the ski resorts were skeptical at first. The ski areas weren't the only areas of concern, "Yes, during the early snowboarding years, snowboarders had a lot of problems with the ski industry, ski resorts and skiers in general" (360guide.info, "Snowboarding History," par. 8). Here are some examples of how Snowboarders were viewed.

Snowboarders:

- $\quad$ Sit on their butts all the time

- $\quad$ Get high

- $\quad$ Can't even stop on the snowboard

- Ruin the slope

- $\quad$ Crash into people

- $\quad$ Have concealed weapons in their baggy clothes

- $\quad$ Are having no fun at all; they snowboard just to piss off their parents (360guide.info, "Snowboarding History," par. 8)

Initially the resorts didn't know how to handle snowboarders, so they banned them completely and "insisted on the use of leashes [a strap that prevents a snowboard from sliding away]" (360guide.info, "Snowboarding History," par. 8). In the 1980's, gaining positive recognition would be the single most important factor for growth for snowboarding to be eventually accepted at resorts (Howe 39).

In 1985 only 39 of approximately 600 ski areas allowed snowboarding at their resorts (snowboarding2.com, "The history of Snowboarding," par. 9). 
However, in 1986 The Snowboarding World Championships were held in Breckenridge, Colorado and brought in 'big money' (Thehistoryof.info, “The History of Snowboarding," 32). Would this 'big money' changes the minds of the resorts?

By 1989 many of the powerhouse resorts succumb to following snowboarding, those resorts are...

\author{
- $\quad$ Squaw Valley, California \\ - $\quad$ Mammoth Mountain, California \\ - $\quad$ Vail, Colorado \\ - $\quad$ Sun Valley, Idaho \\ - $\quad$ Snowbird, Utah. \\ Source: expn.com, "Snowboarding History,” par. 34
}

In their effort to maintain balance and peace resorts even tried offering separate slopes for snowboarders (thehostoryof.net, "The History of Snowboarding," par. 19).

In the 1990's as snowboarding began to gain popularity, "Snowboarders had the stigma of being grungy, live-on-the-edge teenagers who were out to get skiers, but some snow enthusiasts now say that stereotype is overrated and will soon die out" (newsnetbyu.edu, "Snowboarder stereotype squelched, par. 1). To counteract this stigma, "Trendsetters, moved away from the traditional rebellions of piercing and tattooing and toward a more conservative and ironically mainstream stance, with less visual signification, more technically functional clothing, and an overall decrease in identification with the stereotyped snowboarder" (Howe 116).

To reverse the negative stereotype of snowboarders the National Ski Area Association (NSAA), Burton Snowboards ${ }^{\circledR}$, the Professional Ski Instructors of America (PSIA) and the American Association of Snowboard Instructors (AASI) partnered to create the Freestyle Terrain Safety Initiative (NSAA, Safety Programs,” par. 1).

The Freestyle Terrain Safety Initiative is a program that strives to "continue the proper use and progression of terrain parks at mountain resorts, while also delivering a unified message that is clear, concise, and effective" (NSAA, "Safety Programs." par. 2). The program displays consumer information at resorts, refer to Appendix A, which include The Four Points Of Style, "Make a Plan, Look Before You Leap, Easy Style It and Respect Gets Respect" (NSAA, "Safety Programs." par. 3). Today, "98\% of resorts allow snowboarding, and slopes continue to be built just for snowboards" (thehistoryof.net, "The History of Snowboarding," par. 19).

\title{
THE OLYMPICS
}

Although measures were being taken to clean up the sport, in 1994 things took a turn for the worse, "as snowboarders were getting kicked off of Breckenridge for wearing guns, the International Olympic Committee decided to include Snowboarding in the 1998 Winter Olympics in Nagano, Japan" (Howe 153).

Tension was mounting as the, "Two main governing bodies jockeyed for the right to qualify and choose riders to go to the games: the International Snowboard Federation (ISF), a group of snowboarders who had been developing an international circuit for eight years, and the Federation International du Ski (FIS), the skiing organization that had already organized all the Olympic snow sports" (Howe 154).

The Federation International du Ski or FIS for short, was seen as, "more stuffy and bureaucratic," while the International Snowboard Federation (ISF), "Kept an ear tuned to the racers" (Natives.co.uk, "ISF Folds Operations," par. 4).

The Olympic committee, "Recognized the FIS as the sport's official governing body," for the 1998 Nagano, Japan Olympic games, declaring Snowboarding an official sport (Natives.co.uk, "ISF Folds Operations," par. 5).

By 2002, "The International Snowboard Federation, the free-spirited, rider-orientated association that laid the groundwork for snowboarding to become an Olympic sport, has voted to cease operations because of financial problems" (Natives.co.uk, "ISF Folds Operations," par. 1). 


\section{DEMOGRAPHICS}

The ski industry is changing, and at one time alpine skiing dominated the snow sport's world. Today, however, "Snowboarding is by far the fastest-growing segment of what used to be called the ski industry" (outtakes.com, "Snowboarding," par. 2). The Snowboarding Industry, although it may seem young has expanded into a multi-billion dollar industry and as long as it keeps snowing each winter, the industry shows no signs of melting away (Industry Resists Recession 2).

\section{GENDER}

Figure 1 shows that males dominate both the ski and snowboarding industries. (Winterfeelsgood.com, "Snow Sports Statistics," par. 5). According to Ski magazine, $60 \%$ of skiers are male, and $77 \%$ of snowboarders are male ("Numerology,").

Figure 1

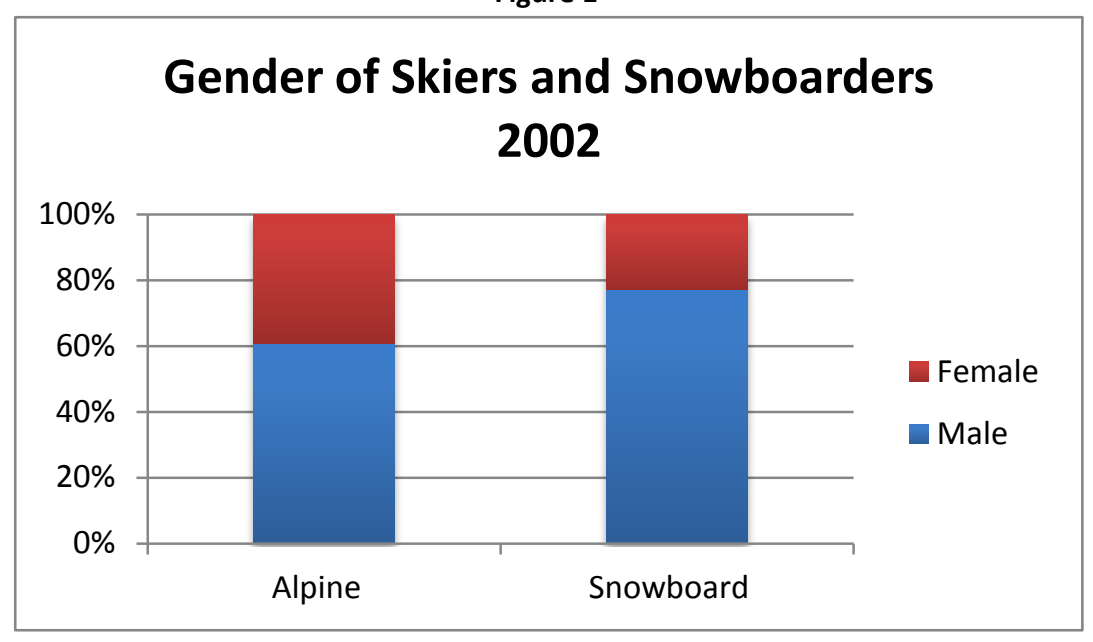

Source: Winterfeeldgood.com, "Snow Sports Statistics," par. 5.

\section{Males}

- $\quad$ Advanced/Expert ability 73\%

- $\quad$ Participate 30+ times/season 68\%

- Wear helmet 63\%

- $\quad$ Season pass-holders $63 \%$

Females

- Beginners

- $\quad$ First time participants

- $\quad$ Lesson takers 53\%

- $\quad$ Equipment renters 50\%

- $\quad$ Participates visiting as part of organized group $48 \%$

Source: National Demographic Study 2005/06

Females are represented in the lower ability, and less avid segments of the market, indicating, "The industry is about as equally effective in introducing first-time trial of snowsports among males and females, but it is less effective in converting females than males into accomplished, frequent participants, and in retaining female participation and reducing dropout over time" (National Demographic Study 5).

However, professional female snowboarders helped encourage young females to get into the sport, "It wasn't until the mid-'90s explosion in the women's recreational market that female pros started making lot of money for their sponsors and moved in to the limelight as the darlings of the Industry" (Howe 120). 
Introducing women and girls to the snowsports industry through groups "May be a relatively effective method of introducing women and girls to snowsports, insofar as women compromise a relatively high share of visitors in groups, and a comparatively high share of women who start participating via a group stick with snowsports in later years" (NSAA, "National Demographic Study," 3).

Age

According to Figure 2 Males aged 17 and under favor snowboarding over alpine skiing (Winterfeeldgood.com, "Snow Sports Statistics," par. 6). Notice how alpine skiers ages 25 to 44 outnumber snowboarders almost 4 to 1 and also how snowboarders decrease by as age increases (Winterfeeldgood.com, "Snow Sports Statistics," par. 6). The 18 to 24 demographic are the most equally balanced with average numbers of both snowboarders and alpine skiers (Winterfeeldgood.com, "Snow Sports Statistics," par. 6). The average snowboarder is quite young only 23.3 years old, and, "Only .3\% are over 65 or under seven years old" (Jones, "Snowboarding," par. 3). The average age of a snowsport participant is 33.2 in 1997/98 and a slight increase to 35.7 in 2004/05 season (National Demographic Study 6). With generations shifting, the demographics of snowboarding will also evolve. Notice the amount18 - 24 subgroup from Figure 2 is now older and categorized in the 25 - 34 subgroup in Figure 3, 5 years later, and has also decreased over $5 \%$. You can also see a healthy growth in the youth market, individuals under the age of 24 who participate in snowboarding (National Demographic Study 6).

Figure 2

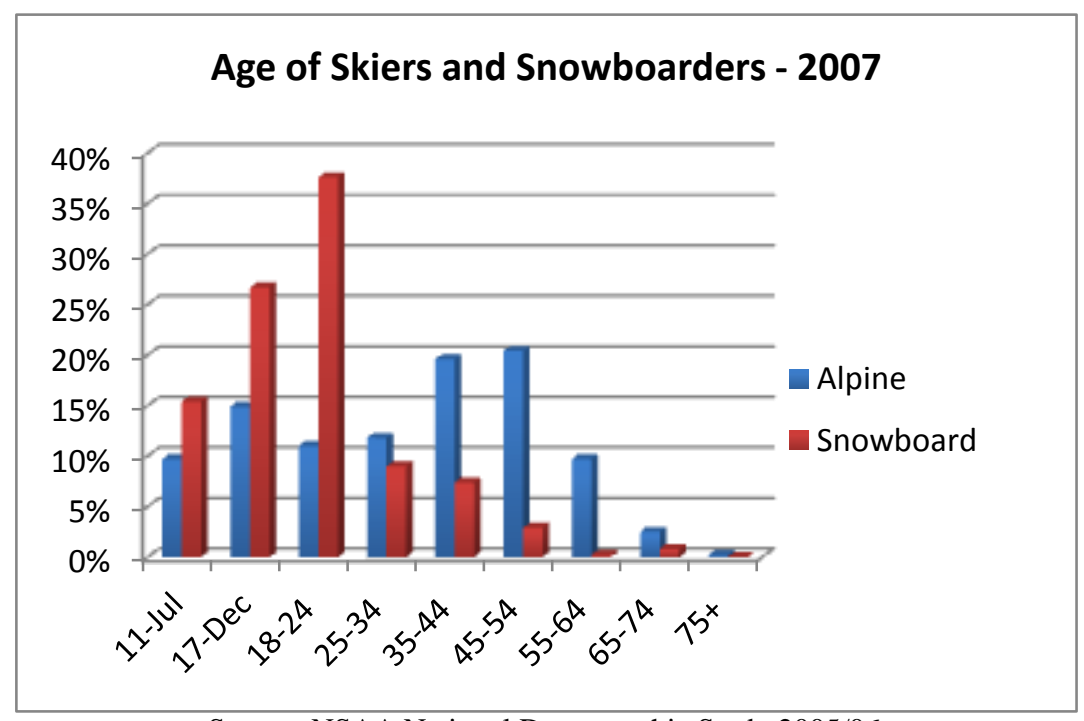

Source: NSAA National Demogranhic Studv 2005/06

\section{Families}

In the $2005 / 06$ season $51 \%$ of snowboarders and skiers came as part of a family with children (National Demographic Study 7). "The second largest segment is singles without children, representing 27 percent of snowsports participants (National Demographic Study 7).

\section{Ethnicity}

The 2005/06 NSAA Demographic study found that $86 \%$ of snowsports participants were white (National Demographic Study 8). "The marital/ethnic mix of visitors has remained fairly stable over time, given the precision available from the survey results" (National Demographic Study 8). "Consistent with historic patterns" minorities only make up 14\% of the ethnic composition (National Demographic Study 8). Minorities are also more likely to use snowboards compared to non-Hispanic Whites (National Demographic Study 8). Minorities who are snowboarding for their first time or classify themselves as a beginner, rent equipment, take lessons, with a median age of 27 are 
reasons why "these factors point to the relatively recent adoption of snowsports among many in minority groups" (National Demographic Study 8).

Figure 3

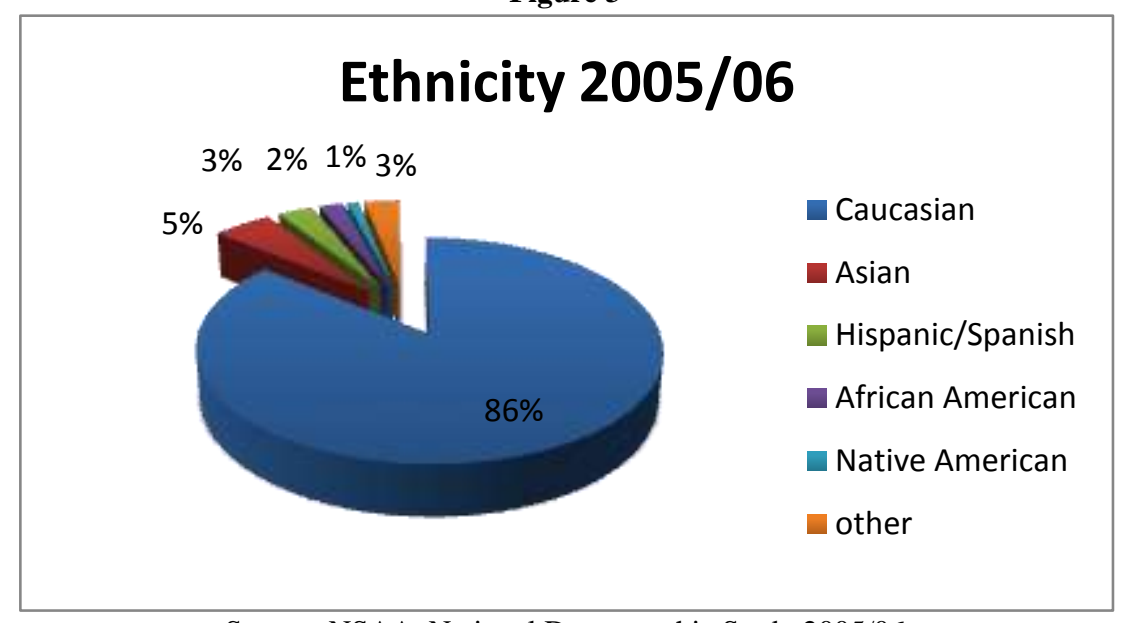

Source: NSAA, National Demographic Study 2005/06

Ethnic and racial minorities will remain key markets for the future growth in the snowboarding industry only representing $14 \%$ of visits in the U.S. market (National Demographic Study 8). The snowboarding industry in concentrated on the youth segment of the minorities demographic hopeful of promising growth if "participants can be retained while new participants are attracted to snowsports" (National Demographic

\section{Geographic Region}

The National Ski Areas Association created geographic regions that snowsports participants travel from and can be broken into six geographic regions illustrated in Figure 4.

Figure 4

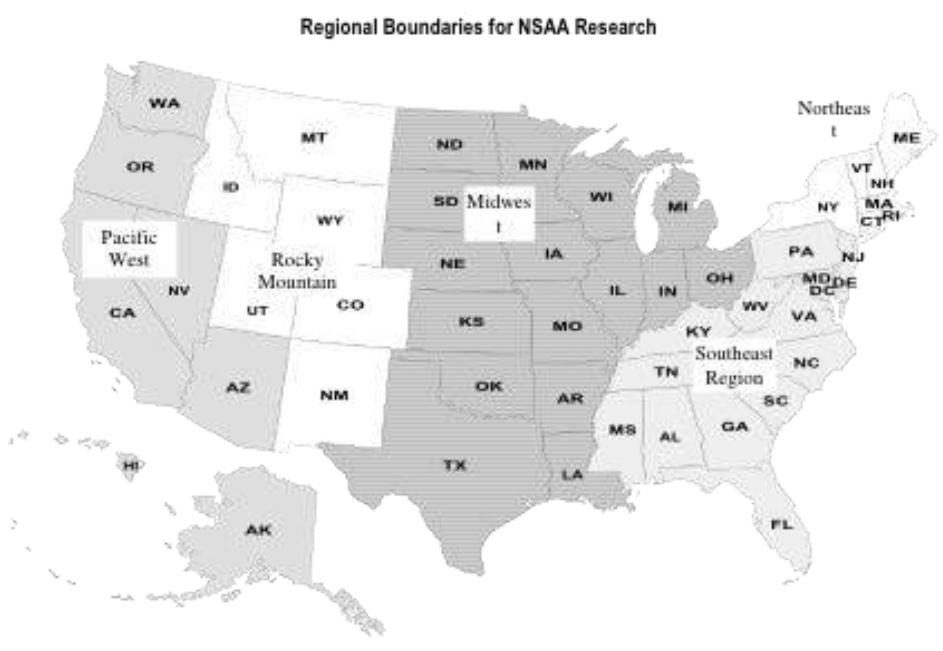

Source: NSAA, 06/07 Ski Industry Report Compendium, 2006 
Below, illustrated in Figure 5 is the estimated volume of skier visits by geographic origin during the 2004/05 and the 2005/06 seasons (National Demographic Study 13).

Figure 5

Estimated Skier Visits by Geographic Origin, 2005/06 vs. 2004/05

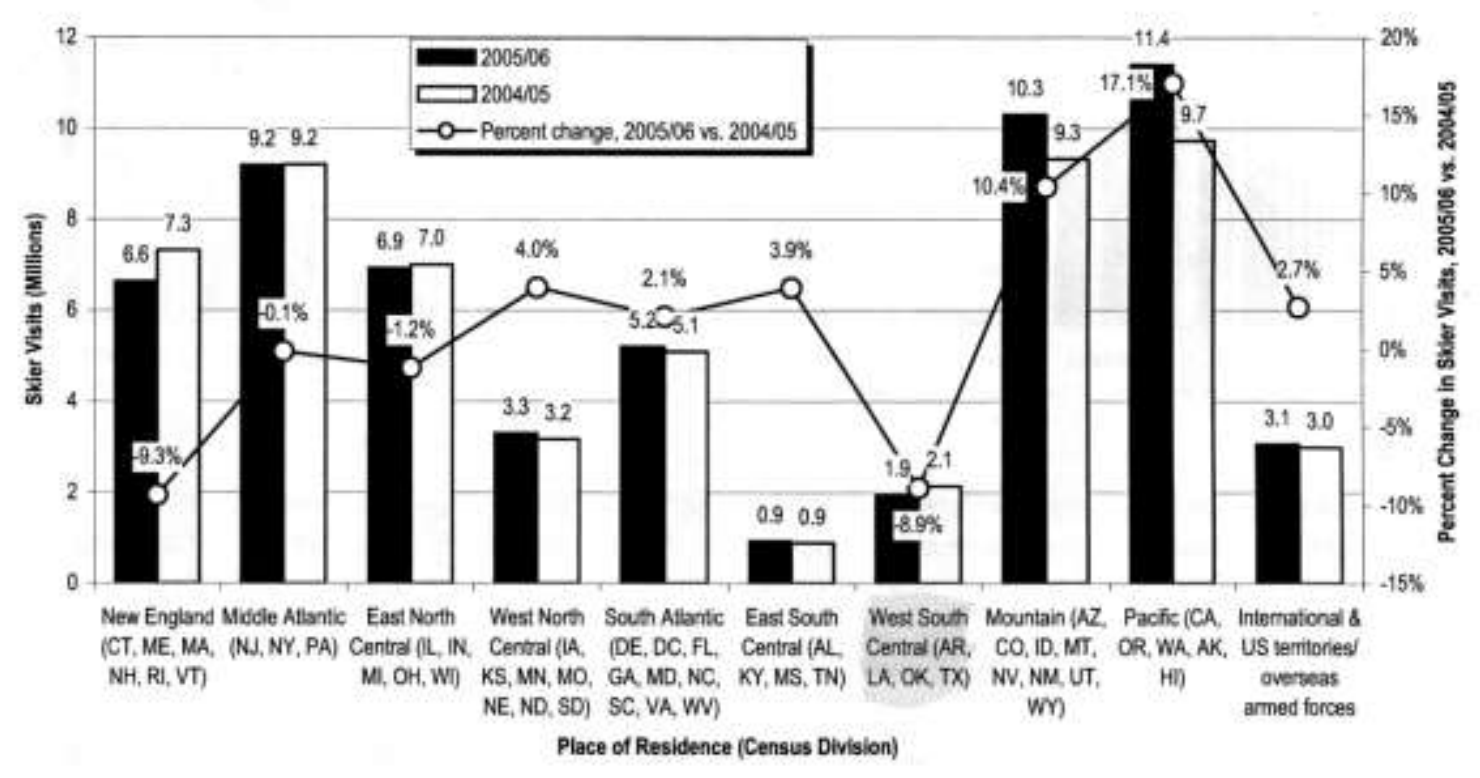

In the 2005/06 season the Pacific Census Division accounted for the most visits, 11.4 million, followed by the Mountain Census Region accounting for $10.4 \%$ of the total annual visits. The Middle Atlantic which includes New York, New Jersey, and Pennsylvania accounted for 9.2 million visits in both the 2004/05 and 2005/06 seasons (National Demographic Study 13). Notable lows exist in the East South Central, West North Central, and International and U.S. territories/overseas armed forces (National Demographic Study 13).

\section{Snowboarding vs. Skiing}

Figure 6 illustrates the number of snowboarders from the years 2000 to 2007 in millions of participants (Snow Sports Fact Sheet par. 3). From the years 2001 to 2003 there is a decline in the number of skiers a decrease in 888,000 participants, while snowboarding increased its participation by 966,000 (Snowsports Fact Sheet par. 3). In 2004 the number of snowboarders surpasses skiers for the first time. However, this is merely a one year anomaly (Fact Sheet par. 3). As the years go on, snowboarding and skiing continue to battle for the most participants. What will the future demographics show, will skiing prevail or will snowboarding take over? 
Figure 6

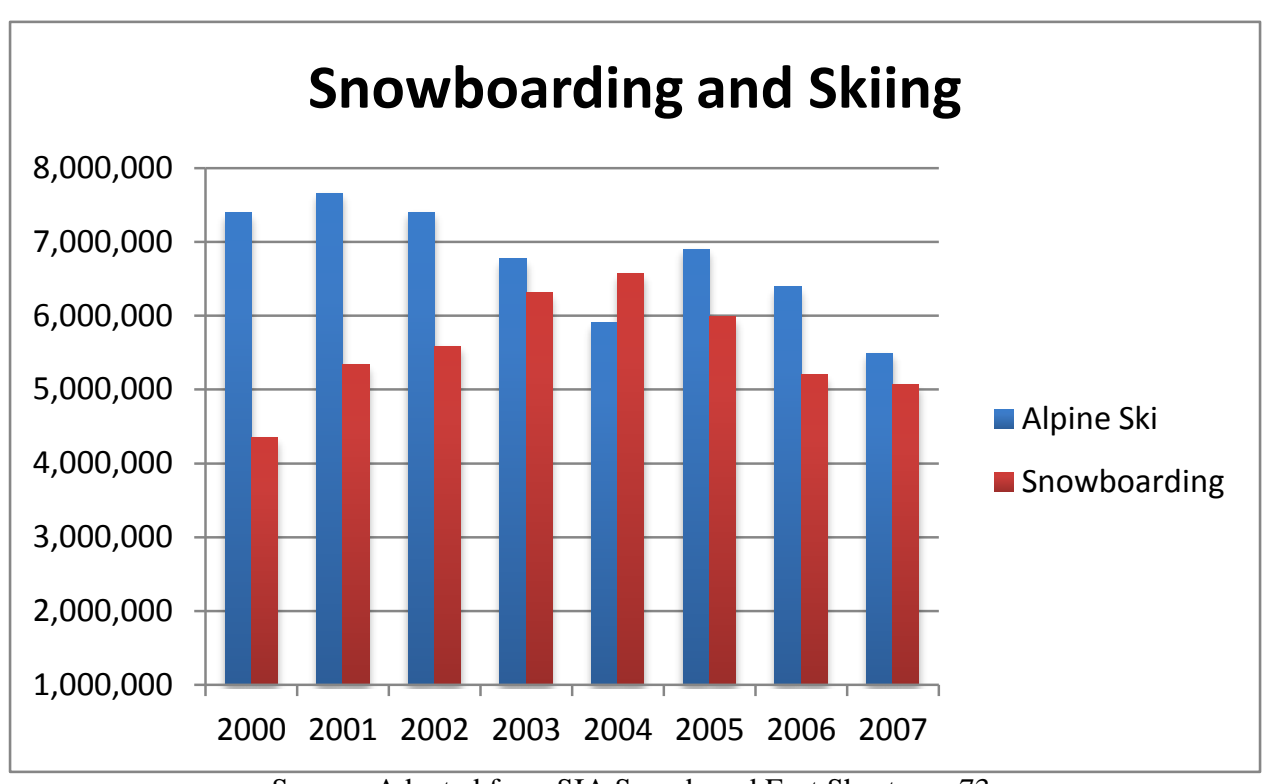

Source: Adapted from SIA Snowboard Fact Sheet par. 73

\section{Teaching Notes}

This case presents an excellent opportunity to discuss market segmentation and how demographics affect segmentation. One can easily recognize the demographic differences between skiers and snowboarders. However, an interesting twist of segmentation is hidden within this case. The case presents the trend of skiing/snowboarding being a family event. In addition, it is clear from the demographics presented that it is highly likely that the parents will be skiers, and the children snowboarders. The question becomes: how does one segment the market when a family unit most likely represents two different segments?

Another interesting teaching opportunity is a discussion of the product life cycle. As presented in the case, skiing days compared to snowboarding days is declining. Is skiing in the mature or even decline stage of the product life cycle? Is there somenhing else, some new technology on the horizon that may eventually replace snowboarding.

Finally, the opportunity exists to discuss the impact of uncontrollable variables on marketing success. It is obvious that skiing and snowboarding is highly dependent upon snow. How would global warming affect the industry? How large is that danger?

In short, this case presents the opportunity to discuss many basic principles in marketing. It is therefore recommended that this case be used at the undergraduate level in a principles course.

\section{AUTHOR INFORMATION}

Kenneth A. Hunt Ph.D. is a Professor of Marketing at Fort Lewis College, Durango, Colorado. Dr. Hunt received his Ph.D. in Marketing from Virginia Tech. He has published over forty articles in Journals such as: Journal of Retailing, the Journal of Marketing Science and the Journal of Business Research. E-mail: hunt_k@fortlewis.edu (Corresponding author)

\section{Will Secor}




\section{WORKS CITED}

1. “2006/07 Ski Report Industry Research Compendium.” National Ski Areas Association (NSAA). 2006.

2. "Back in the Day an in Depth look at the History Snowboarding and Burton Snowboards." Burton.com. 15 Mar 2009. http://akamai.burton.com/2008/PDF/08_BackintheDay.pdf

3. "Burton Snowboards Inc." fundinguniverse.com. 15 March 2009.

http://www.fundinguniverse.com/company-histories/Burton-Snowboards-Inc-Company-History.html

4. $\quad$ Cameron, Sarah. "Rope on the Nose.” Shredbetties.com. 15 Mar 2009. 2008

www.shredbetties.com/articles/story/rope_on_the_nose_snurfing_for_girls

5. $\quad$ Crane, Lee. "Snowboard History Timeline Part 1(1960's-70's)." Expn.com. 30 Nov 2003. 16 Mar 2009. http://expn.go.com/snb/s/snowboard timeline 60 70.html

6. $\quad$ Dortch, Shannon. "Skiing, Skating and Shredding." BNET Business Network. FEB 1996. 26 MAR 2009. http://findarticles.com/p/articles/mi_m4021/is_n2_v18/ai_17966593

7. $\quad$ Davis, Kelly. "The White Papers: The U.S. Snow Sports Industry Resists Recession.” SnowSports Industries America. 16 OCT 2008. 21 FEB 2009.

http://www.snowsports.org/industry resources/the white papers Path: Industry Resists Recession.

8. $\quad$ Extreme Snowboarding. New York: Universe Publishing 1998.

9. $\quad$ "His name Is Sherman Poppen." Flakezine.com. 1996. 28 Feb 2009. http://www.flakezine.com/poppen.html

10. Howe, Susanna. (Sick) A Cultural History of Snowboarding. New York: St. Martin's Griffin, 1998.

11. "ISF Folds Operations.” Natives.co.uk 05 Jul 2002. 18 March 2009. http://www.natives.co.uk/news/2002/0702/05fed.htm

12. "Kottle National end of Season Survey 2007/08" RRC Associates. 2008.

13. Miller, Chris. "Snowboarding and the Rise to Olympic Competition."EzineArticles.com. 2009. 18 Mar 2009. http://EzineArticles.com/?expert=Chris_Milller

14. Monson Snowboards, "Snowboarding Construction." 2007. 1 APR 2009. http://www.snowboarding.com/howto/construct/boardconstruction.html

15. "Snowboarding History." Snowboarding2.com. 2006. 3 Mar 2009. http://www.snowboarding2.com/history.php

16. Ray grass Desert Morning News, "Skiers Hit Slopes in Record Numbers." BNET Business Network. 18 May 2005. 22 Mar 2009. http://findarticles.com/p/articles/mi_qn418

17. "Sales by Region." Snowsports Industries America. 2008. 06 APR 2009. http://www.snowsports.org/industry_resources/research_reports/sales_by_state Path: sales by region

18. "Snowboarding history and who invented the snowboard." SportsWinterpark.com November 15, 2008. 13 Mar 2009. http://www.sportswinterpark.com/tag/sherman-poppen

19. "Safety Programs.” National Ski Area Association. 2009. 18 March 2009. http://www.nsaa.org/nsaa/safety/smart-style

20. Schwartz, Shannon. "The History of Snowboarding - From Garages to the Olympics." Thehistoryof.net 10 Sept 2008. 18 Mar 2009. http://www.thehistoryof.net/history-of-snowboarding.html

21. "Snowboard History." http://360guide.info. 16 Mar 2009. http://360guide.info/snowboarding/snowboardhistory.html?Itemid=59

22. "Snowboarding Up 31\% According To NSGA Study." Transworld Business. 21 May 2001. 29 MAR 2009. http://business.transworld.net/2001/05/21/snowboardingup-31-according-to-nsga-study/

23. "Sustainable Slopes." National Ski Areas Association (NSAA). June 2001. http://www.nsaa.org/nsaa/environment/sustainable_slopes Path: 2001.

24. "The American Ski Industry-Reasons for Optimism in the 21st Century." BBC Research and Consulting. 31 MAR 2005. 30 MAR 2009. www.nsaa.org

25. "The History of Snowboarding, Part 2." Method Magazine. 05 Nov 2007. 16 Mar 2009. http://www.methodmag.com/125.html?\&tx_ttnews[tt_news]=3531\&tx_ttnews[ackPid]=113\&cHash=97d3 d923a4\%22\#1979s

26. Jones, Tim. "Snowboarding." Outtakes.com 1997. 20 Mar 2009. http://www.outtakes.com/winter/winter.snowboard.html

27. $\quad$ RRC Associates, "National Demographic Study 2005/06."National Ski Areas Association. 2006. 
28. " "Snow Sport Statistics.” Winterfeelsgood.com. 2009. 21 Mar 2009.

http://www.winterfeelsgood.com/winterfeelsgood.php?section=news\&page=basic stats\#Gender

29. "SIA Snow Sports Fact Sheet" SIA: SnowSports Industries America. 2008. 29 Mar 2009.

http://www.snowsports.org/industry_resources/research_reports/sia_snow_sports_fact_sheet

\section{APPENDIX A}

\begin{tabular}{|c|c|c|c|c|c|c|c|}
\hline \multicolumn{8}{|c|}{$\begin{array}{l}\text { Geographic Origin of Skiers/Snowboarders by NSAA Resort Region } \\
2005 / 06 \text { Enhenced Date } \\
\text { Cells Greater thon } 20 \text { Percent ave Alighlighted }\end{array}$} \\
\hline \multirow[b]{2}{*}{ Place of Residence (U.S. Census Regian \& Division) } & \multirow[b]{2}{*}{$\begin{array}{c}\text { Overall- } \\
\text { All Resorts }\end{array}$} & \multicolumn{5}{|c|}{ RESORT LOCATION (NSAA REGION" } & \multirow[b]{2}{*}{$\begin{array}{c}\text { Percent of } \\
\text { US Pop'n (2005) }\end{array}$} \\
\hline & & $\begin{array}{c}\text { Northeastern } \\
\text { Resorts }\end{array}$ & $\begin{array}{c}\text { Southeastem } \\
\text { Resorts }\end{array}$ & $\begin{array}{l}\text { Midwestern } \\
\text { Resorts }\end{array}$ & $\begin{array}{l}\text { Rocky Mtn } \\
\text { Resorts }\end{array}$ & $\begin{array}{c}\text { Pacific West } \\
\text { Reserts }\end{array}$ & \\
\hline \multicolumn{8}{|l|}{ Northeast Census Region } \\
\hline New England Census Division (CT, ME, MA, NH, RI, VT) & $11.3 \%$ & $46.9 \%$ & $0.6 \%$ & $0.1 \%$ & $3.0 \%$ & $0.8 \%$ & $4.8 \%$ \\
\hline Midde Allantic Census Division (NJ, NY, PA) & $15.6 \%$ & $40.3 \%$ & $44.0 \%$ & $1.9 \%$ & $6.3 \%$ & $1.0 \%$ & $13.6 \%$ \\
\hline Subtotal & $269 \%$ & $87.2 \%$ & 44.68 & $2.0 \%$ & $9.4 \%$ & $1.8 \%$ & $18.4 \%$ \\
\hline \multicolumn{8}{|l|}{ Midwest Census Region } \\
\hline East North Centrai (IL, IN, MI, OH, WI) & $11.8 \%$ & $2.4 \%$ & $2.7 \%$ & $62.7 \%$ & $6.7 \%$ & $1.5 \%$ & $15.6 \%$ \\
\hline West North Central (IA, KS, MN, MO, NE, ND, SD) & $5.6 \%$ & $0.2 \%$ & $0.2 \%$ & $276 \%$ & $5.0 \%$ & $0.6 \%$ & $67 \%$ \\
\hline Suttotal & $17.4 \%$ & $2.6 \%$ & $2.9 \%$ & $90.4 \%$ & $11.8 \%$ & $2.2 \%$ & $22.3 \%$ \\
\hline \multicolumn{8}{|l|}{ South Census Region } \\
\hline South Atlantic (DE, DC, AL, GA, MO, NC, SC, VA, WV) & $8.8 \%$ & $2.5 \%$ & $45.8 \%$ & $0.7 \%$ & $9.4 \%$ & $1.8 \%$ & $19.0 \%$ \\
\hline East South Central (AL, KY, MS, TN) & $1.6 \%$ & $0.1 \%$ & $4.5 \%$ & $2.3 \%$ & $1.9 \%$ & $0.6 \%$ & $5.9 \%$ \\
\hline West South Central (AR, LA, OK, TX) & $3.3 \%$ & $0.2 \%$ & $0.3 \%$ & $0.6 \%$ & $8.2 \%$ & $1.4 \%$ & 11.48 \\
\hline Suctotal & $13.7 \%$ & $2.8 \%$ & $50.6 \%$ & $3.6 \%$ & $19.5 \%$ & $38 \%$ & $36.3 \%$ \\
\hline \multicolumn{8}{|l|}{ Wost Census Region } \\
\hline Mountain (AZ, CO, ID, MT, NV, NM, UT, WM & $17.5 \%$ & $0.2 \%$ & $0.1 \%$ & $0.5 \%$ & $46.1 \%$ & $5.6 \%$ & $68 \%$ \\
\hline Pacfic (CA, OR, WA, AK, HI) & $19.3 \%$ & $0.4 \%$ & $0.4 \%$ & $0.3 \%$ & $6.5 \%$ & $826 \%$ & $18.2 \%$ \\
\hline Subtotal & $36.8 \%$ & $0.5 \%$ & $0.5 \%$ & $0.8 \%$ & $52.7 \%$ & $88.2 \%$ & $230 \%$ \\
\hline \multirow{3}{*}{$\begin{array}{l}\text { Overseas/International } \\
\text { US overseas - armed forces, Samoa, VI, PR, etc. } \\
\text { Intemational }\end{array}$} & & & & & & & \\
\hline & $0.2 \%$ & $0.2 \%$ & $0.1 \%$ & $0.0 \%$ & $0.1 \%$ & $0.3 \%$ & NA \\
\hline & $5.1 \%$ & $6.6 \%$ & $1.4 \%$ & $32 \%$ & $6.6 \%$ & $3.7 \%$ & NUA \\
\hline Subtatal & $5.2 \%$ & $6.8 \%$ & $1.4 \%$ & $3.2 \%$ & $6.7 \%$ & $40 \%$ & NA \\
\hline Grand Fotal & $100.0 \%$ & $100.0 \%$ & $1000 \%$ & $100.0 \%$ & $100.0 \%$ & $1000 \%$ & $100.0 \%$ \\
\hline \multicolumn{8}{|c|}{$\begin{array}{l}\text { 'NSAA resort regions are defined as follows: } \\
\text { Northeast: CT, MA, ME, NH, NY, VT, RI } \\
\text { Southeast: AL, GA, KY, MD, NC, NJ, PA, TN, VA, WV } \\
\text { Midwest: IA, LL, IN, MI, MN, MO, ND, NE, OH, SD, WI } \\
\text { Rocky Mountain: CO, ID, MT, NM. UT, WY } \\
\text { Pacific West: AK, AZ, CA, NV, OR. WA }\end{array}$} \\
\hline
\end{tabular}

Source: NSAA, "National Demographic Study,” pg. 8. 